\title{
A MÜVÉSZETI NEVELÉS JÓ GYAKORLATAI HAZAI MÚZEUMOKBAN - MÚZEUMPEDAGÓGIA, A PEDAGÓGUSOK NÉLKÜLÖZHETETLEN ESZKÖZTÁRA
}

\section{Takács Anett}

Kaposvári Egyetem, Pedagógiai Kar

A modern múzeumok a látogatót fókuszba helyezve, a tudomány, a technika, a történelem, a müvészetek komplex interpretálására törekszenek. Tradicionális feladataik mellett egyre hangsúlyosabb szerepet kap az oktató-nevelő funkció, mely egyúttal feltételezi az iskolák és múzeumok közötti együttmüködés szorosabbá válását. A pedagógusok számára kiváló eszköz az élményközpontú pedagógia alkalmazása a múzeumokban. A pedagógushallgatók számára e színes eszköztár ismerete, alkalmazásának elsajátítása későbbi munkájukban „,hatékony fegyverré" válhat.

A tanulmány célja, hogy a dokumentumelemzés módszerével, néhány hazai jó gyakorlat tükrében bemutassa, hogyan állítható a múzeumpedagógia eszköztára a tanulás, nevelés, különös tekintettel a müvészeti nevelés szolgálatába, bizonyítsa, hogy e módszertan ismerete a pedagógusok számára nélkülözhetetlen, helye a pedagógusképzésekben indokolt.

\section{Tanulás múzeumi környezetben}

A múzeum interaktív környezetben, élményközpontú módszerekkel, segítheti, eredményesebbé teheti az iskolai tanulást. Kiállításai sajátos módokat kínálnak a formális, nem-formális és informális tanulásra egyaránt, egyszerre van bennük jelen az affektivitás, az empirizmus, a kísérletezés.

A múzeum speciális közege elősegíti a komplex látásmód kialakítását, fejlesztését; összefüggésekre mutat rá; elmélyíti, kiegészíti, gyakoroltatja az iskolában a tanórán szerzett tudást; megmagyarázza az ismereteket; szemléltet; felkelti az érdeklődést adott témával kapcsolatban; továbbgondolkodásra ösztönöz; segíti a kooperációt; fejleszti a különböző képességeket, készségeket (Vásárhelyi és Sinkó, 2004).

A múzeumi tanulás az iskolai tanulási helyzetekkel szemben általában alkalomszerü, egyszerre több tantárgy bevonására ad lehetőséget, több érzékszerv bevonásával hat a szereplőkre, előtérbe helyezi a kooperatív módszerek alkalmazását, mellőzi az iskolai értékelési formákat. Az iskolai tanulási helyzetekkel szemben legfőbb előnye a „különleges környezet”, a gyakorlati tapasztalatszerzésen alapuló élményközpontú ismeretszerzés, a nevelés minél több területének bevonása (testi-, értelmi-, érzelmi-, erkölcsi-, esztétikai-, müvészeti-, egészség-, környezeti-, állampolgári-, multikulturális nevelés) a tanulási folyamatba (Vásárhelyi és Kárpáti, 2009).

\section{A múzeumok és a köznevelési intézmények közötti együttmúködés erősödése}

A múzeumlátogatások, múzeumi foglalkozások bekapcsolása az iskola életébe Magyarországon nem újdonság. Az osztálykirándulások az 1970-es évektől általában múzeumlátogatásokról szóltak. A „múzeumból ki, múzeumba be” módszer eredménye sok esetben azonban csak kavargó összbenyomás, negatív múzeumi attitủd. A mostani gyakorlat, az ad hoc múzeumlátogatások helyett az iskolák és múzeumok közötti együttmüködés erősítésére, rendszeresítésére 
irányul, ami a nyugat-európai múzeumok többségénél már természetes. Ehhez a folyamathoz az iskolák és múzeumok közötti együttmüködés létfontosságú. A Múzeumok Mindenkinek Program (2003), a 2006-ban létrehozott Múzeumi Oktatási és Képzési Központ, valamint a Nemzeti Fejlesztési Ügynökség 2007ben elindított operatív programjai (TÁMOP 3.2.8/10/B: Múzeumok Mindenkinek Program - Múzeumok oktatási-képzési szerepének erősítése; TIOP 1.2.2/08-1 Múzeumok iskolabarát fejlesztése és oktatási-képzési szerepének infrastrukturális erősítése pályázat) felélénkítették az iskolák és múzeumok kooperációját. „A MOKK által kidolgozott Múzeumok Mindenkinek Program, a Múzeumok oktatásiképzési szerepének erősitése - Központi módszertani fejlesztés címü projekt célja: „A kompetenciafejlesztő közoktatás érdekében újszerü múzeumpedagógiai megoldások, valamint a múzeumok és a közoktatási intézmények közötti együttmüködések kialakítása" (Vásárhelyi, 2009. 8. o.).

Az operatív programok kapcsán kialakított oktató- és foglalkoztató terek, IKT-pontok, eszközök és az ezekre épülö múzeumpedagógiai programok az iskolabarát múzeum kialakítását célozták így számos lehetőséget teremtettek és teremtenek a szórakozva tanulásra (Vásárhelyi, 2009).

\section{Múzeumpedagógia}

A múzeumpedagógia fogalmának meghatározása a jelenleg használatban lévő gazdag terminológia miatt (múzeumi kreatív foglalkozás, múzeumi közmüvelődés, múzeumi népművelés, múzeumi mediáció, múzeumi közönségkapcsolatok, múzeumandragógia, felnőtt múzeumpedagógia, múzeumi gerontagógia) nehéz feladat (Koltai, 2011). Nyugat-Európa múzeumaiban a gyerekek oktatása, felnőttek oktatása, oktatási programok családoknak, kifejezésekkel találkozunk (Cseri, 2009), jellemző továbbá a tanulás (lásd például British Museum honlapján: iskola, tanárok, család, felnőtt felbontásban) kifejezés használata is ${ }^{1}$.

Az egyik legismertebb definíció szerint a múzeumpedagógia: „az iskolán kívüli ismeretszerzés, ismeretközvetítés sajátos, múzeumban megvalósuló formájával foglalkozó pedagógiai elmélet és gyakorlat a múzeum gyüjteményi anyaga, kiállításai, az ott folyó kutatómunka és a múzeum látogatói közötti közvetítőtevékenység azon területe, amely a gyermek- és ifjúsági korosztállyal foglalkozik" (Palotainé, 2003. 11. o.). A csoportosításokban és a definícióban is megfigyelhető az életkor szerinti csoportosítás.

Amíg a múzeumandragógia a felnőttekre, a múzeumgerontagógia az idősekre fókuszál, a múzeumpedagógia célcsoportjai elsősorban az óvodás és iskolás korosztály. Legfontosabb feladata: az óvodán-, iskolán kívüli oktatónevelő munka megvalósítása, koordinálása, dokumentálása; a különböző célcsoportokhoz igazodó differenciált didaktikai módszerek kidolgozása; az új és régi látogatók figyelmének felkeltése, és aktív résztvevővé nevelése; az életkori sajátosságokat figyelembe vevő programok szervezése; kiadványok szerkesztése (Kócziánné, 2002). Legfontosabb célja a tárgyi és személyi tartalmak élményszerü megismertetése és a múzeumlátogatóvá nevelés.

A „szórakozva tanulás” (,edutainment”) elvén alapuló múzeumpedagógiai módszertan, az egyes célcsoportok életkori sajátosságait figyelembe véve, a tapasztalati tanulást, a komplexitás elveit előtérbe helyezve interpretálja a múzeumi tartalmakat.

\footnotetext{
1 www.britishmuseum.org/learning.aspx
} 
A múzeumpedagógia révén a gyermekek játék közben formálják esztétikai, tárgyi, viselkedési kultúrájukat, identitásukat. Játék közben sajátítják el, például a helyes múzeumi viselkedési normákat, ismerik meg különböző korok művészetét, épületeit, tárgyi világát (Hajnal, é.n.).

A múzeumpedagógia módszerei: a tárlatvezetés; feladatlap, foglalkoztató füzet; manuális tevékenység, tárgykészítés; drámapedagógiai módszerek; vetélkedö, társasjáték; vita; projekt-módszer; történetmesélés (Koltai, 2011).

E módszertant alapul véve a hazai múzeumokban a következő programtípusokkal találkozhatunk: tematikus interaktív foglalkozások (jelmezes történelmi játékok, történeti játszóház); tematikus komplex foglalkozások; tematikus múzeumi órák; kreatív, kézműves foglalkozások; múzeumi szakkörök, táborok; tematikus hetek; szabadegyetemek; előadások.

E programok célközönsége elsősorban az óvodás, általános iskolás és középiskolás korosztály. Családok, kisebb csoportok önállóan is feldolgozhatják a kiállításokat, ugyanakkor elterjedtebbek az iskolai csoportok számára kidolgozott múzeumi programok.

\section{Múzeumpedagógia, mint a múvészeti nevelés eszköze a jó gyakorlatok tükrében}

A Szépmüvészeti Múzeum „Színezz zenét Cézanne-nal!” programján 250 gyermek és felnőtt énekelt és festett Cézanne képeire. A „Színezz zenét!” egy audiovizuális játék, amelynek célja egy adott képi világ kreatív átélése a zene eszközeivel.

A foglalkozás során a négytöl tízéves korú gyermekek megismerkedtek a festészet alapfogalmaival, kipróbálhatták, milyen modellt állni egy olyan lassan dolgozó müvésznek, mint Cézanne. Különféle szerep- és szituációs játékok segítségével beleképzelhették magukat a francia festő híres képeibe ${ }^{2}$.

A Petőfi Irodalmi Múzeum (PIM) kibővített kiállítótere, a Mesemúzeum és Meseműhely az öt-tíz éveseket várja. Állandó kiállításának tárgya a magyar tündérmese világa, ahol mese utat járhat be a látogató: a meseindító üveghegyen átkelve, próbákat teljesítve, akadályokat leküzdve juthat el az áhított „felekirályságig”3.

Óvodásoknak és általános iskolásoknak szól az állandó Petőfi Sándor kiállításhoz kapcsolódó „Még a ládára is felszáll”: Petőfi Sándor vándorlásai című program. „A költő hosszú útról tér haza otthonába, és meglepődik, hogy a tyúkot a lakásban leli. De honnan érkezik a poéta, merre járhatott? A foglalkozás középpontjában a költő vándorlásai és útiládája állnak. Hová kísérhette a költőt ez a rejtélyes darab, milyen tárgyakat tárolhatott benne? Mi minden történhetett vele és gazdájával a vándorlások során?” A foglalkozás aktív testmozgásra, úgynevezett ,,petőfitnesz”-re épül.

A Petőfi-kiállítás dagerrotípiáján a költő valódi arca tekint a nézőre. De ez csak egy a rengeteg arca közül. E gondolat köré épül az Arcostársak címü foglalkozás. A Ki vagyok én? Kalandfüzet segítségével a diákok Petőfi szerepébe lépve dönthetnek különféle élethelyzetekben, és döntésük szerint haladnak tovább a kiállítási térben. „Ahány kitöltő, annyi Petőfi-életút és személyes Petőfi-kép.” A program második részében egy arcbehelyettesítő szoftver által elkészül Petőfi

\footnotetext{
${ }^{2}$ http://www.szepmuveszeti.hu/hirek/szinezz-zenet-cezanne-nal-798

${ }^{3} \mathrm{http}: / /$ www.mesemuzeum.hu/rolunk
} 
és a szerepjátékot végigkalandozó közös képe, amit birtokosa megoszthat különböző webes felületeken ${ }^{4}$.

A Ludwig Múzeum bemutatja a kortárs magyar képzőművészet jelentős alkotóit, feltérképezi a kortárs művészet legjellemzőbb trendjeit. A „Ludwigban” a diákok a mütárgyakhoz nemcsak hozzáérhetnek, de időnként ki is próbálhatnak egy-egy müalkotást (például a Lakner Antal: Munkaállomás címü kiállítás „kondigépeit”).

A múzeumpedagógiai kínálatában iskolai tananyag kiegészítésére másfélórás foglalkozások (amelyeken akár a geometriáról is szerezhetnek ismeretet a gyerekek a kortárs mủalkotásokon keresztül), családi délelöttök és egyéb programok szerepelnek ${ }^{5}$. Óvodásoknak és általános iskola alsó tagozatosainak ajánlják az Öt érzék címü foglalkozást. A gyerekek a kortárs művészet segítségével fedezhetik fel érzékszerveiket.

A tíz-tizennégy éveseknek szóló Térhódítás címü program keretében a tér fogalmát, tartalmát járják körül, illetve megnézik, hogy a képzőművészet tereiben miként lehet tájékozódni, a művészek milyen tereket hoznak létre, és azok mit jelentenek. „A foglalkozás tematikai egységei: a térben való tájékozódás lehetőségei, a külső és belső tér, a térkép és a makett szerepe a valóságos tér megismerésében, térbeli tájékozódás a képzőművészeti alkotásokon, valóságos tér és a müalkotás, illuzionisztikus tér és a müalkotás. A program tartalmaz csoportos és egyéni munkaformákat, tájékozódást segítő feladatokat, drámajátékot, kreatív rajzfeladatot. A programhoz alkotófeladat is rendelhető: Perspektíva-szobor alkotás, kis csoportokban"6.

Müködtetnek egy kimondottan pedagógusok számára szervezett kortárs müvészetpedagógiai mühelyt is (Ped.Kedd), melynek célja a kortárs müvészeti (nemcsak képzőmüvészeti) ismeretek gyarapítása, innovatív, alternatív pedagógiai módszerek bemutatása valamint fórum, alkotóműhely, közösségteremtés. Szakmai konferenciái a müvészeti nevelés témaköreit, kérdéseit, újdonságait járják körbe, meghívott előadók részvételével. Gondot fordítanak a pedagógusok szemléletformálására is ${ }^{7}$.

A jelenkori magyar müvészeti törekvéseket és a nemzetközi irányzatokat bemutató Mủcsarnok múzeumpedagógiai programjaiban is fontos szerepet játszik a müvészeti nevelés. Az „Óperenciás tengeren” címü, hat-tíz éves korosztálynak szóló program során a kisiskolás csoportok, mialatt egy végtelen történetet találnak ki, mesélés közben illusztrálják is azt. Az így keletkező képekből, bármeddig folytatható, spirális forma jön létre. A „Tér-vers" foglalkozás keretében 11-14 évesek tesznek kísérletet egy közös (végtelen) vers megírására, mely összehangolt mozgás és gondolkodás végeredménye. A megszületett mü egy nagyméretü Möbius szalagra kerül, a szöveg összeolvad, nem lesz kezdete és vége $^{8}$.

A vidéki múzeumok között mintaszerü a győri Városi Müvészeti Múzeum tevékenysége. 2010-ben a Művészetek utcája - összművészeti fesztivál és családi nap - szervezője Győrben a Városi Müvészeti Múzeum volt. A színes művészeti programokat (például „A barokktól napjainkig” - Harsonakvartett-koncert; „A ese helye.” A Gyermekmúzeum társasjátékai gyerekeknek; „Élő szoborjáték.”

\footnotetext{
${ }^{4} \mathrm{http} / / / \mathrm{www} . \mathrm{pim} . \mathrm{hu}$

${ }^{5} \mathrm{http}: / /$ kunszt.postr.hu/gyerekek-es-muzeumok

${ }^{6}$ www.ludwigmuseum.hu

7 www.ludwigmuseum.hu

${ }^{8} \mathrm{http} / / /$ www.mucsarnok.hu/new_site/index.php?lang=hu\&inf_id=25
} 
Ilies Teofil és Virág Tímea pantomimesek; „Állatorigami.” Jászberényi Balázs origami foglalkozása gyerekeknek és felnőtteknek; „Nemezelés.”; „Macskakő szerenád." A Transzfolk Együttes müsora...) egy mini konferencia kísérte: Mủvészet és/vagy nevelés. Mủvészeti nevelés múzeumon innen és túl címmel.

A TÁMOP - 3.2.11/10/1 című pályázati felhívásra (Nevelési-oktatási intézmények tanórai, tanórán kívüli és szabadidős tevékenységeinek támogatása) a "Maszatoló - Müvészeti nevelés a Városi Müvészeti Múzeumban óvodások és iskolások számára" címü projekttel pályázott a Múzeum. A projekt keretében összesen 114 foglalkozást bonyolítottak le 2659 gyermek részvételével (2010. augusztus 15 - 2011. augusztus 31. között).

A múzeum 10 nevelési-oktatási intézménnyel kötött együttmüködési megállapodást. Az iskolai, óvodai nevelést kiegészítő, tantervhez kapcsolódó programok mellett (müvészettörténet, vizuális környezetkultúra) a gyermekek személyiségfejlődése, művészeti és kreatív képességeinek a kibontakozása is szerepet kapott. Lényeges célként jelölték meg a kulturális nevelés, a kapcsolatteremtő, önkifejező, problémamegoldó képességek, az egészséges személyiség fejlesztését múzeumi környezetben.

Hasonló projektjük a TÁMOP-3.2.13-12/1-2012-0133 Kulturális intézmények részvétele a tanórán kívüli nevelési feladatok ellátásában „Müvészeti nevelés a győri Váczy Péter Gyüjteményben” címü projekt.

Az intézmény múzeumpedagógiai programjainak legfőbb célcsoportjai az óvodások, általános iskolások és a középiskolások. Az óvodáskorúak pedagógusai kilenc állandó program közül válogathatnak. Ilyen például a Radnai Gyüjteményhez kapcsolódó „Kirándulás Szivárványországba” című program, melynek során egy tanulságos történetet hallgatnak a gyerekek a Szitakötőről, a színekröl és a Napról, majd megismerik Egry József Szivárvány címü alkotását és megfestik Szivárványország házait, lakóit.

A Kovács Margit Állandó Kiállítás programja a „Mese a Múzeumban”. A kiállításon szereplő kerámiákat népmesei szituációban ismerik meg a gyerekek, majd agyagszobrokat vagy dombormüveket készítenek a mese szereplőiről.

A hét-tíz éves korosztályt 11 különféle programmal várja a múzeum. A Váczy Péter Gyüjteményben $a$ „Játék Mátyás király udvarában” címü foglalkozás keretében Mátyás királyról hallgatnak a gyerekek mesét, megismerkednek udvartartásával, palotájával. Kiválasztják a kiállítótérben azokat a tárgyakat (bútor, használati tárgy, dísztárgy), melyek Mátyás udvarában is előfordulhattak. Illusztrációt készítenek Mátyás meséjéhez.

A „Huszárok a múzeumban” címü program Háry János történetét eleveníti fel Kovács Margit kerámia figuráiban a Kovács Margit Állandó Kiállításban. A főhős zenei, irodalmi, képzőmüvészeti ábrázolásának megismerése után minden tanuló elkészíti papírból saját Háry-figuráját. Szintén e kiállításhoz kapcsolódik a „Családi körben Kovács Margit figurái között” címü foglalkozás, melyen a családi élet pillanatait megörökítő alkotásokról beszélgetve figyelhetik meg a tanulók, hogy milyen müvészi eszközökkel fejezi ki a keramikus a szereplök érzelmeit. A foglalkozás második felében dombormüvet készítenek saját családjukról.

A középiskolás korosztályt tizenegy különféle program várja, mint a Radnai Gyüjteményhez kapcsolódó „A müvész és modellje”, melynek középpontjában a portré, az emberi alak ábrázolása áll, Szőnyi István müveinek kontextusában. Feladatlapos tárlatvezetés során a tanulók megismerik Szőnyi alkotásait, képein ábrázolt modelljeit. A foglalkozás végén a tanulók portrét rajzolnak. 
Borsos Miklós Állandó Kiállításhoz kapcsolódó Litera-TÚRA címü programon irodalmi müvek illusztrációit, nagy írók portréit keresik meg a tanulók Borsos művei között. A bemutatott írók (Janus Pannonius, Szabó Lőrinc, Radnóti Miklós) egyikének verséhez illusztrációt készítenek lavírozott tus vagy diófa pác technikával ${ }^{9}$.

A hazai múzeumi kínálat természetesen ennél jóval sokszínűbb. E néhány jó gyakorlat, ugyanakkor már kellő bizonyítéka annak, hogy a kiállítások nagyszerüen alkalmazhatók tanulási célokra, továbbá az élményközpontú, több tantárgyon átívelö, komplex módszertan, az interaktív múzeumi környezetben jól hasznosítható, többek között, mủvészeti nevelési célokra.

\section{Hol tanulhatnak a pedagógusok múzeumpedagógiát?}

A pedagógusok bevonása a múzeumpedagógiai programokba, a pedagógusmúzeumpedagógus állandó kooperáció jelenleg még nem elég kiterjedt. Az interaktív környezet iránti nyitottság nagymértékben függ a pedagógus személyes attitüdjétől, az élményközpontú módszerek megismerésétől.

E módszertan megismerésére, alkalmazásának elsajátítására jelenleg néhány intézményben van lehetőség, mint például a 2006-ban létrejött Múzeumi Oktatási és Képzési Központban (MOKK), mely a Szabadtéri Néprajzi Múzeum egyik igazgatóságaként müködik. Országos feladatokat lát el, amelyek között kiemelt területet jelent a felnőttképzési program, a szakmai továbbképzések kidolgozása, akkreditáltatása, szervezése. 2008-ban a Skanzen a Felnőttképzési Akkreditáló testület által minősített, akkreditált felnőttképző intézmény lett. Képzéseinek célcsoportjai a múzeumi szakemberek és a pedagógusok. A pedagógusoknak szóló képzéseket a Pedagógiai Akkreditációs Testület (PAT) akkreditálja (Káldy, 2010).

A MOKK jelenleg pedagógusoknak kínált képzése: az „Iskolák és múzeumok partnersége" címü harmincórás pedagógus-továbbképzés, melynek célja, hogy „a pedagógusok ismerjék meg azokat a múzeumi lehetőségeket és módszereket, melyek jól hasznosíthatók a kompetencia alapú oktatás számára", további cél „rávilágítani arra, hogy a pedagógusok a tantervhez illeszkedő minőségi, a múzeumi tárgyon, gyüjteményen alapuló múzeumpedagógiai foglalkozásokkal tudják kiegészíteni és bővíteni a diákok ismereteit, tudását az élményszerü tanulás jegyében”, illetve „fontos elvárás hogy képessé váljanak oktatási és muzeális intézmények közötti együttmüködések megvalósítására"10.

A Skanzen Múzeumpedagógiai Osztálya által kínált, a saját kiállításaira épülő speciális képzések: a „Néphagyomány-éltetés az óvodai nevelésben” és „A honés népismeret szemléltető tanítása"11.

A MOKK képzései mellett egyes múzeumok (például Magyar Nemzeti Múzeum, Szépmúvészeti Múzeum, Petőfi Irodalmi Múzeum, Néprajzi Múzeum, Ludwig Múzeum, Magyar Természettudományi Múzeum...) egy-két napos továbbképzéseket kínálnak a nyitott pedagógusoknak.

A Magyar Nemzeti Múzeum akkreditált pedagógus-továbbképzései (A 60 órás OM által akkreditált a „Magyarország története az államalapítástól 1990-ig” címü állandó kiállításának tematikus megismerése, múzeumpedagógiai feldolgozási lehetőségei továbbképző tanfolyam; a Históriás Történeti Játszóház

\footnotetext{
${ }^{9}$ www.artmuz.hu

${ }^{10} \mathrm{http}: / /$ mokk.muzeumokmindenkinek.hu/kepzes/kepzes.php?IDK=4

$11 \mathrm{http}: / /$ skanzen.hu/?fm=2\&am=5\&dd=89
} 
30 órás akkreditált módszertani továbbképzés) átmenetileg szünetelnek. Ezek mellett külön szakmai programokat ajánlanak pedagógusoknak (pl. „Témahetek, témanapok, szakkörök a múzeumban" címmel módszertani bemutató) ${ }^{12}$.

A Szépművészeti Múzeum „Múzeumpedagógia tanároknak” címmel, egész- illetve félnapos továbbképzéseket szervez pedagógusoknak, melyek célja, hogy a közoktatásban dolgozó kollégák megtanulják önállóan használni a Szépmüvészeti Múzeum állandó és időszaki kiállításainak anyagát a tanórákon és a múzeumlátogatás során. A kurzus keretében a résztvevőknek lehetősége nyílik arra, hogy kipróbáljanak olyan feladat- és foglalkozástípusokat, illetve játékokat és módszereket, amelyek segítenek a műalkotásokat élővé varázsolni ${ }^{13}$.

2011-töl müködnek a PIM Mühely egynapos tanár-továbbképzési programjai: „Az Irodalmi Múzeum kulisszatitkai - Szakmai-irodalmi mélyfúrások" címmel.

A példákat a Néprajzi Múzeum: „Mire jó a múzeum? - a drámapedagógia, mint a felfedezés új módszere a csoportos múzeumi nevelésben" címủ akkreditált múzeumi szakmai továbbképzése zárja.

A múzeumok mellett föiskolai, egyetemi tanulmányok során ismerkedhetnek a pedagógusok a múzeumpedagógia eszközeivel, elsősorban fizetős szakirányú továbbképzések formájában (Eötvös Loránd Tudományegyetem Pedagógiai és Pszichológiai Kar, Kaposvári Egyetem Pedagógiai Kar), illetve választható tárgyként (pl. Kaposvári Egyetem Pedagógiai Karán az óvodapedagógus BA szak és a vizuális környezetkultúra tanár MA szak mintatantervében).

Mind a múzeumi képzések, mind a szakirányú továbbképzések szük célcsoport számára elérhetők. A bachelor- és masterképzésekbe beépítve e módszertani tudás jóval tágabb körben terjeszthető.

\section{Miért tanuljon a pedagógus hallgató múzeumpedagógiát?}

Európa nyugati országaiban bevált gyakorlat a múzeumok és iskolák partnersége, amelynek hangsúlyozása az EU-s pályázatokban is egyre nagyobb szerepet kap.

Indíték lehet továbbá a pedagógusokat érintő néhány új kihívás - mint az iskolán kívüli fejlesztés, a mindenkori tudáshoz és annak felhasználásához tartozó felkészültség, alkalmazkodás és fluencia -, illetve kompetenciarepertoár-elvárás (Walter és Takács, 2011).

Az új követelmények gyakorlati alkalmazásának kiváló helyszínei lehetnek a múzeumok, ugyanakkor csak egy módszertanilag és szakmailag felkészült pedagógus tudja kihasználni adottságait. A múzeumpedagógiai eszköztár alkalmazása változatossá, élményekben gazdaggá varázsolja a tanórákat, ezáltal eredményesebbé teszi a tanulási folyamatot, az így elsajátított tartalmak hatékonyabban beépülnek a már megszerzett ismeretek közé, könnyebben elöhívhatóak, sokkal inkább eredményeznek lehorgonyzott tudást (Walter és Takács, 2011).

A múzeumlátogatók jelentős része az iskolák szervezett csoportjaiból kerül ki. A múzeumban szerzett első tapasztalatok döntik el, hogy a diákok később állandó múzeumlátogatókká, mủvészetek iránt nyitott emberekké válnak-e. Ehhez azonban szükséges, hogy a jövő pedagógusai tájékozottak legyenek a múzeumi foglalkozások megtervezésében, kivitelezésében.

\footnotetext{
${ }^{12}$ www.hnm.hu,

${ }^{13} \mathrm{http}: / /$ www.szepmuveszeti.hu/muzeumpedagogia_tanaroknak
} 


\section{Összegzés}

A modern múzeumok tradicionális funkciói mellett egyre hangsúlyosabbá válik az oktatásban betöltött szerep, a múzeumok és a közoktatás közötti rendszeres kapcsolat kialakítása.

A múzeumok speciális atmoszférája, a szórakozva tanítás/tanulás elvére épülő színes múzeumpedagógiai módszertan nagyszerüen alkalmazható különféle tanulási, nevelési célokra (beleértve és kihangsúlyozva a művészeti nevelést).

A pedagógusok számára hatékony eszköztárat jelent az élményközpontú pedagógia és a kooperatív módszerek alkalmazása a múzeumi közegben, így az új kihívásokon - oktató, nevelö, fejlesztő, facilitáló szerepek - túl, aktuális kérdés a pedagógusok múzeumpedagógiai tudásának bővítése.

\section{Irodalom}

Cseri Miklós (2009): Az ismeretátadás, a múzeumpedagógia helye és szerepe a magyar múzeumokban. In: Bereczky Ibolya és Sághi Ilona (szerk.): Szórakoztatva tanulni, tanulva szórakozni! Projektmódszer a múzeumpedagógiában. Szabadtéri Néprajzi Múzeum - Múzeumi Oktatási és Képzési Központ, Szentendre. 4-6.

Hajnal M. Hajnalka (é.n.): Múzeumpedagógia az óvodában. letöltés helye: http://jovoiskolaja.hu/oviparade/pedagogia/ letöltés ideje: 2013. május 31.

Káldy Mária (2010): Felnőttképzési programok a Múzeumi Oktatási és Képzési Központban. In: Kurta Mihály és Pató Márta (szerk.): Múzeumandragógia $1 \mathrm{Az} I$. Országos Múzeumandragógiai Konferencia válogatott anyaga. Borsod-AbaújZemplén megyei Múzeumi Igazgatóság - Szentendrei Szabadtéri Múzeum, MiskolcSzentendre. 177-181.

Kócziánné Szentpéteri Erzsébet (2002): Múzeumok, közművelődés és múzeumpedagógia, In: Kovács Judit (szerk.): Múzeumok a „köz müvelődéséért”. Pulszky Társaság-Magyar Múzeumi Egyesület, Budapest. 15-16.

Koltai Zsuzsa (2011): A múzeumi kultúraközvetités változó világa. A múzeumi kultúraközvetités pedagógiai és andragógiai szempontú vizsgálata. Gondolat Kiadó, Budapest.

Palotainé Simon Ilona (2003): A múzeumpedagógia elméleti alapjai. In: Foghtüy Krisztina és Szepesházyné Kurimay Ágnes (szerk.): Múzeumpedagógiai tanulmányok I. ELTE PPK Oktatásmódszertani Központ, Budapest. 11-18.

Vásárhelyi Tamás (2009): Az egész életen át tartó tanulás, az iskola és a múzeumok. In: Vásárhelyi Tamás (szerk.): Múzeum és iskola. Múzeumok a közoktatás szolgálatában. Kutatási jelentés. Szabadtéri Néprajzi Múzeum - Múzeumi Oktatási és Képzési Központ, Szentendre. 151-152.

Vásárhelyi Tamás (2009): Múzeum és tanulás - egész életen át. In: Vásárhelyi Tamás és Kárpáti Andrea (szerk.): A múzeumi tanulás kézikönyve. Magyar Természettudományi Múzeum, ELTE TTK Multimédiapedagógiai és Információtechnológiai Központ, Budapest. 81-82.

Vásárhelyi Tamás és Sinkó István (2004): Múzeum az iskolatáskában. Nemzeti Tankönyvkiadó, Budapest.

Walter Imola és Takács Anett (2011): Pedagógusok új szerepben, múzeumpedagógiai módszerek alkalmazása a gyakorlatban - mint új perspektíva. In: Pinczésné Palásthy 
Ildikó (szerk.): A református tanitóképzés múltja, jelene, jövője. Kölcsey Ferenc Református Tanítóképzés Föiskola, Debrecen. 130-134.

Aki lusta az iskolában, lelkes a múzeumban. (KUNSZTBLOG) letöltés helye: http://kunszt.postr.hu /gyerekek-es-muzeumok letöltés ideje: 2013. március 17.

Színezz zenét Cézanne-nal! Interaktív játék képekkel és hangokkal a Szépmüvészeti Múzeumban. letöltés helye: http://www.szepmuveszeti.hu/hirek/szinezz-zenetcezanne-nal-798 letöltés ideje: 2013. június. 1. 